\title{
Anna Kieszkowska*
}

\section{RODZINY UWIĘZIONYCH I ICH MIEJSCE W ŚRODOWISKU LOKALNYM}

\section{FAMILIES OF PRISONERS AND THEIR PLACE IN THE LOCAL ENVIRONMENT}

\begin{abstract}
Streszczenie: Przebywanie jednego $z$ członków rodziny przez dłuższy czas w warunkach izolacji więziennej staje się czynnikiem, który narusza w różnym zakresie dotychczasowe funkcjonowanie rodziny i utrudnia lub zakłóca relacje społeczne. Oddzielenie od najbliższych w znacznym stopniu warunkuje zachowania poszczególnych osób oraz funkcjonowanie rodziny jako całości, a w szczególności uniemożliwia wypełnianie przez pozostałych członków określonych zadań i ról rodzinnych, chociaż pozostają bolesne doświadczenia i brak pozytywnych odniesień do zdarzeń jakie miały miejsce w rodzinie.
\end{abstract}

Słowa kluczowe: rodziny uwięzionych, stygmatyzacja, sytuacja życiowa, traumatyczne przeżycia

Received: 08.2018

\begin{abstract}
Being one of the family members for a long time under conditions of prison isolation becomes a factor that violates, to varying degrees, the family's existing functioning and hinders or disturbs social relations. Separation from the closest relies largely on the behavior of individuals and the functioning of the family as a whole, and in particular prevents other members from fulfilling certain family tasks and roles, although there are painful experiences and lack of positive references to events that took place in the family.
\end{abstract}

Key words: imprisoned families, stigmatization, life situation, traumatic experiences

Accepted: 09.2018

\footnotetext{
* Uniwersytet Jana Kochanowskiego w Kielcach Zakład Profilaktyki Społecznej i Resocjalizacji
} 


\section{Wprowadzenie}

Współczesna rodzina coraz bardziej narażona jest na zagrożenia ze strony wpływu różnych zjawisk społecznych, będących w dużym stopniu skutkiem procesów transformacji ustrojowej, zmian ekonomicznych, zjawisk o charakterze kulturowym, upowszechnienia się nowych stylów funkcjonowania w społeczeństwie, a także niebezpieczeństw związanych z utratą bliskich członków rodziny lub ich trudną sytuacją prawną prowadzącą do stygmatyzacji przez lata członków rodziny w środowisku lokalnym.

W przypadku uwięzienia sprawcy czynu problem nie dotyczy jedynie osoby przebywającej w warunkach izolacji więziennej, ale całego systemu rodzinnego, stąd najbardziej adekwatnym określeniem wydaje się pojęcie uwięzionej rodziny [por. Marczak 2012] i uwięzionych jednostek mającej relacje z osobami skazanymi. Uwięzienie rodziny polega na jej krótkim lub długoterminowym odseparowaniu od środowiska rodzinnego, lokalnego oraz nieprawidłowym w nim funkcjonowaniu osób, których bliscy znaleźli się za murami zakładu karnego, ze względu na znaczne ograniczenie lub całkowite zawieszenie w pełnieniu ról partnerskich i rodzicielskich.

Pobyt jednego z członków rodziny przez dłuższy czas w warunkach izolacji więziennej staje się czynnikiem, który narusza dotychczasowe funkcjonowanie rodziny - jako systemu, a członkowie rodziny stają się również osobami odrzuconymi i potępionymi przez otoczenie sąsiedzkie. Oddzielenie od najbliższych, nawet jeżeli nie występowały silne więzi rodzinne - zgodnie z założeniami systemowego modelu związków wewnątrzrodzinnych - w znacznym stopniu warunkuje zachowania 
poszczególnych osób oraz funkcjonowanie rodziny jako całości, a w szczególności utrudnia wypełnianie przez pozostałych członków określonych zadań i ról rodzinnych, chociaż pozostają bolesne doświadczenia i brak pozytywnych odniesień do zdarzeń jakie miały miejsce $w$ rodzinie [Kieszkowska 2012].

W trudnej więc sytuacji życiowej znajdują się rodziny uwięzionych, a więc takie których członkowie ze względu na łamanie norm społecznych, wchodzenie w konflikty społeczne, popełnienie czynu przestępczego, przebywają w placówce penitencjarnej. Rozpoznanie sytuacji trudnych wymaga rozpatrywania w obszarze funkcjonowania poszczególnych członków tych rodzin w jej własnym środowisku i relacji rodzinnych, jak również w społecznym funkcjonowaniu w środowisku sąsiedzkim, zawodowym.

Ze względu na szybkie tempo rozwoju, zmianę warunków życia, sytuacji wymagających od człowieka podejmowania szybkich decyzji, braku doświadczenia wchodzenia w nowe sytuacje, często dochodzi samoczynnie do zagrożenia patologią. Rodzina $\mathrm{w}$ jednej chwili traci kontakt $\mathrm{z}$ osobą pozbawioną wolności, a jej możliwości zaradcze są często znikome i bez żadnego wparcia ze strony środowiska czy instytucji. Zatem istnieje potrzeba aktualnych badań prowadzonych w rodzinach osób uwięzionych, poznanie funkcjonowania poszczególnych osób, a w szczególności dzieci pozostawionych bez opieki i nierozumiejących odrzucenia społecznego. Istotne z punktu widzenia staje się również dążenie do włączenia poszczególnych grup społecznych do życia z rodzinami uwięzionych w ich środowisku lokalnym. 
Konsekwencją przebywania mężczyzny/ojca (lub matki) w izolacji jest zachwianie nie tylko ról ojcowskich, ale także autorytetu rodzica i swoim czynem wskazywanie na określone sposoby funkcjonowania w społeczeństwie. Izolacja rodzica prowadzi do braku możliwości zaspokajania potrzeb emocjonalnych i towarzyskich członków rodziny, zanikania więzi uczuciowych, braku oparcia dla dzieci, ograniczenia stosowania metod wychowawczych i sprawowania opieki, zaburzeń spostrzegania dzieci i ich potrzeb rozwojowych oraz do zakłócenia i deformacji w sposobie komunikacji z dzieckiem.

\section{Stygmatyzacja osadzonego a wykluczenie członków rodziny}

Osadzenie w warunkach izolacji więziennej powoduje całkowitą zmianę środowiska skazanego z jednoczesnym odseparowaniem go od środowiska rodzinnego, problemów i wydarzeń życiowych ważnych dla wszystkich członków rodziny. Utrudnia to w znacznym stopniu kontaktowanie się z osobami najbliższymi oraz ogranicza jego udział w życiu rodzinnym i prawidłowym wypełnianiu ról partnerskich, małżeńskich i rodzicielskich, nawet jeśli one kiedyś wypełniane były tylko w niewielkim stopniu [Marczak, 2011; Kieszkowska 2011]. Można zatem przyjąć, że uwięzienie jednego z członków rodziny pociąga za sobą negatywne skutki nie tylko dla funkcjonowania osoby, którą to spotkało, ale dla całego systemu rodzinnego. Również w trakcie pobytu rodzica w zakładzie karnym na dzieci negatywny wpływ wywiera brak modelu pełnienia roli ojcowskiej oraz pozbawienie ich opieki rodzicielskiej, co staje się publicznym problemem pociągającym za sobą konsekwencje edukacyjne, kulturowe, ekonomiczne 
i społeczne z racji wycofywania się dzieci z życia społecznego lub wchodzenia na drogę przestępczą.

Na skutek uwięzienia jednego z członków rodziny dochodzi do zachwiania i dezorganizacji życia pozostałych członków w rodzinie. Sytuacja społeczna członków rodzin osób pozbawionych wolności przejawia się między innymi w zachwianiu poczucia bezpieczeństwa finansowego, wsparcia emocjonalnego, co wiąże się z samopoczuciem społecznym.

Samopoczucie jest ogólną oceną konkretnej sytuacji, obciążoną subiektywnym widzeniem teraźniejszości, kiedy dochodzi do porównywania pozycji rodziny i skazanego, analizowania sytuacji pod kątem strat i zysków związanych z izolacją osoby, uciążliwości i problemów natury psychofizycznej [Kotlarska-Michalska, Rusanen, Niemela, 1977].

Stres związany z aresztowaniem i skazaniem członka rodziny ma bardzo duży wpływ na dalsze losy i jakość funkcjonowania tej rodziny. W stosunku do osadzonego pojawiają się ambiwalentne odczucia związane z popełnionym czynem, ponadto rodziny muszą borykać się ze stygmatyzacją ze strony otoczenia, problemami materialnymi, dotkliwie odczuwają samotność związaną z podejmowaniem nowych ról społecznych, często realizacji obowiązków za osobę pozbawioną wolności, tj. samotnego rodzica czy żywiciela rodziny [Pawełek, 2009].

Osadzenie w zakładzie karnym przekłada się na wszystkie sfery życia rodziny w środowisku lokalnym. Sytuacja społeczna, ekonomiczna i wewnętrzna rodzin pozbawionych wolności ulega całkowitemu pogorszeniu po ich osadzeniu w zakładzie karnym, natomiast w dużym stopniu odczuwane jest odrzucenie członków rodzin przez społeczeństwo ze względu 
na sytuacje związaną z czynem przestępczym. Osadzenie jednego z członków przyczynia się do rozluźnienia więzi z dziećmi i partnerem, zerwania kontaktów z bliskimi, poczucia zagrożenia ze strony społeczeństwa wysyłającego negatywne komunikaty w stronę rodziny.

Rodzina w sytuacji traumatycznych przeżyć ma poczucie odtrącenia i potępienia, sama żywi urazę do skazanego, a jednocześnie czuje się odrzucona i niezrozumiana przez społeczeństwo. Nie podejmuje też właściwych działań na rzecz rozwiązania i poprawy własnej sytuacji społecznej i nieuchronnie wycofuje się z życia społecznego. Jedynie pomoc ze strony instytucji i wykorzystanie określonych form terapeutycznych stanowi szansę na odbudowę relacji zarówno w środowisku, jak i z osobą odbywającą karę pozbawienia wolności.

Członkowie rodziny powinni uzyskać stosowne informacje, poradę, uczestniczyć w warsztatach wspierających, w określonych formach poradnictwa, poznać sposoby ratowania samych siebie, swojej rodziny i zadbać o zachowanie odpowiednich relacji ze skazanym oraz ze środowiskiem lokalnym. Właściwie realizowana profesjonalna pomoc przyczynić się winna do złagodzenia traumy jakiej doznała rodzina i otoczenie społeczne.

Prowadzona resocjalizacja skazanego w zakładzie karnym wynika z konsekwencji zaistnienia relatywnie sprzężonych ze sobą czynów i działań, wyrażonych w kategoriach: winy, kary, wybaczenia, które należy analizować dwukierunkowo. Wina pojawia się po zaistnieniu czynu popełnionego przez jednostkę przeciwko jednostce, społeczeństwu lub czynu popełnionego przez społeczeństwo innemu społeczeństwu. 
Z kolei społeczeństwo karze jednostkę za popełnione czyny, ale równocześnie wymierza samoswoistą karę w formie piętnowania, dyskryminowania, wzmacniania negatywnych odczuć i odtrącenia bądź wydatkowania energii i środków w celu przywrócenia społeczeństwu. Pozytywne przykłady zachowań wynikają z subiektywnych odczuć społecznych związanych z zastosowaniem kary wobec określonej osoby.

Należy podkreślić, że dojrzałe i odpowiedzialne społeczeństwo wybacza jednostce dokonanie czynu przez podejmowanie wobec niej działań resocjalizacyjnych i terapeutycznych w takim stopniu, aby osoba mogła powrócić do środowiska, zaś osadzony w zakładzie karnym, poprzez analizę dotychczasowego zachowania podejmuje wysiłek przemiany samego siebie i po części uwalnia również społeczeństwo od winy za zaistnienie działań destruktywnych na jego rzecz. Więź społeczna daje poczucie siły, pozwala odnajdywać sens życia, wypełnia pustkę po stracie tego, co było szczególnie ważne, a także daje odpowiedź na pytanie, że jednostka jest sobą i ma w zasięgu rodzinę. Człowiek po opuszczeniu zakładu karnego musi mieć poczucie przynależności do grupy, poczucie akceptacji i bezpieczeństwa, aby mógł stawać się sobą i mieć szansę spłacania długu społeczeństwu.

Niewątpliwie to rodzina odgrywa najważniejszą rolę w procesie reintegracji społecznej skazanych. Musi być zatem sojusznikiem administracji penitencjarnej w jej wysiłkach resocjalizujących, a tym samym być istotnym elementem tej pracy i brać w niej udział. Żaden program resocjalizacyjny nie będzie mógł wykazać się sukcesami, jeśli nie uwzględni się tych ludzi, z którymi więzień będzie żył po wyjściu z zakładu karnego, a którzy sprzyjać mu będą $w$ podejmowaniu ról społecznych pozostających w zgodzie z akceptowanymi w społeczeństwie wartościami, wzorami i normami 
zachowań. Biorąc pod uwagę taki stan rzeczy, istotne znaczenie ma kontakt skazanych z rodzinami i społeczeństwem w środowisku lokalnym, aby powrót do środowiska życia był sprawą naturalną dla otoczenia.

Dzięki kontaktowi ze społeczeństwem, skazani podtrzymują pozytywny obraz samego siebie, odnoszą satysfakcję emocjonalną, utrzymują silną identyfikację z rodziną, nabywają i utwierdzają się w przekonaniu, że są nadal ważni dla swoich najbliższych, a zatem motywują się do poprawy/zmiany swojego zachowania i rozwiązania trudnych problemów w rodzinie. Rodzina może być łącznikiem osoby skazanej ze społeczeństwem i życiem jakie toczy się poza murami więziennymi, chociaż zazwyczaj ze względu na swoje uwięzienie w środowisku lokalnym musi się borykać ze swoimi problemami. Aby trwać, istnieć i rozwijać się, musi posiadać określone więzi w tym społeczne.

Kara pozbawienia wolności nie może odbywać się kosztem zerwania więzi rodzinnych łączących skazanych z rodziną, ponieważ więź ta leży u podstaw życia danej rodziny, a co za tym idzie przesądza o jego integracji lub dezintegracji i niejednokrotnie to właśnie ona stanowi o możliwości i skuteczności wszelkich oddziaływań stosowanych wobec osadzonego. Rozluźnienie bądź zerwanie więzi potęguje trudności w odnalezieniu się w środowisku otwartym po opuszczeniu zakładu karnego [Muskała, 2006].

Wcześniejsze zachowania przestępcze oraz pobyt w izolacji więziennej nie tylko osłabiają, ale wręcz powodują zerwanie więzi społecznych dewianta z jego najbliższym otoczeniem, jak również bardzo często wyobcowują rodzinę przestępcy w wymiarze socjalnym i psychicznym, a także naznaczają jego środowisko nauki, pracy, kręgi sąsiedzkie 
i towarzyskie. Dlatego też odbudowanie właściwych więzi w otoczeniu sąsiedzkim, rodzinnym musi być traktowane w całym systemie pomocy postpenitencjarnej jako najważniejsze, zarówno na etapie przygotowania osadzonego do życia za murami więzienia, jak i po jego opuszczeniu, a przede wszystkim winno być wspierane $\mathrm{w}$ trakcie pobytu w zakładzie karnym każdego skazanego.

Z pewnością nie da się naprawić zaburzonych relacji z rodziną i otoczeniem w miejscu pracy, nauki, poprawić na zasadzie przelotnych kontaktów w trakcie przepustki czy też w okresie bezpośrednio poprzedzającego zwolnienie z zakładu karnego. Powinien to być proces ciągły, rozpoczęty już w momencie osadzenia do czasu opuszczenia placówki a nawet po wyjściu z więzienia na wolność [Ambrozik 2007, 190], kontynuowany przez określone grupy specjalistów wspomagających rodzinę byłego więźnia.

Osoby, które popełniły czyn karalny i zostały skazane na karę pozbawienia wolności, a następnie zwolnione, to bez względu na wiek biologiczny i czas izolacji oczekują przede wszystkim wsparcia, zrozumienia, akceptacji od najbliższej rodziny i za wszelką cenę przebaczenia i pomocy w wyjściu z trudnej sytuacji. Podczas uwięzienia ujawnia się zwłaszcza opiekuńcza funkcja rodziny oraz psychohigieniczna uwzględniająca zaspokojenie szczególnie potrzeb emocjonalnych. Z kolei po opuszczeniu placówki resocjalizacyjnej dochodzą inne funkcje, kiedy rodzina staje się często jedynym, podstawowym łącznikiem osoby zwolnionej ze światem społecznym. Obejmuje więc wszystkie dziedziny życia człowieka oraz zajmuje się najtrudniejszymi sprawami, a do takich niewątpliwie należy fakt popełnionego przestępstwa, spotykający się z potępieniem przez państwo 
prawa i społeczeństwo. Zadomowienie i schronienie w środowisku i rodzinie wydaje się spełniać podstawową rolę $w$ społecznej readaptacji opuszczających zakład karny. Nieliczne przykłady pomyślnie zakończonego procesu readaptacji społecznej pozwalają wysunąć tezę, że w cały proces resocjalizacji winno się angażować środowisko rodzinne, które przejmie opiekę i udzieli wsparcia po opuszczeniu placówki resocjalizacyjnej, względnie też wówczas, kiedy udaje się byłemu osadzonemu założyć rodzinę. Bowiem zadomowienie w życiu rodzinnym, zatrudnienie i bezpieczeństwo finansowe są najlepszą gwarancją dla właściwego powrotu byłego więźnia do normalnego życia w społeczeństwie. Poza rodziną to oddziaływanie środowiskowe ma na celu zapewnienie wsparcia emocjonalnego dla osób podejmujących wysiłek ponownej readaptacji społecznej. Przychylne usposobienie najbliższego otoczenia może niewątpliwie pomoc skazanemu w rozwiązywaniu istotnych życiowych spraw i problemów oraz pozytywnie zadziałać na zmianę postaw osoby poddanej probacji. Niektóre osoby ze środowiska społecznego byłego więźnia mogą mieć duży wpływ na jego pozytywne zachowanie dlatego, że łączą je z nim ścisłe więzi. Dlatego też takie osoby w określonym stopniu i zakresie powinny być podmiotami współuczestniczącymi w procesie wychowania i przygotowania więźnia do wolności [Ambrozik, 2007].

\section{Wybrane przykłady funkcjonowania rodzin osób przebywających w warunkach izolacji więziennej}

Rodzina dla każdego człowieka jest bardzo ważna, zawsze stanowi punkt odniesienia, nawet w sytuacji, kiedy jednostka nie może liczyć na jej wsparcie lub nie posiada wcale bliskich. Rodzina w przypadku osób, które funkcjonują 
W związkach formalnych i nieformalnych z byłymi więźniami, uwikłana jest z reguły $\mathrm{w}$ wiele konfliktów i problemów osobistych, rodzinnych zawodowych i społecznych przeżywanych i doświadczanych przez jej członków. Oczekiwanie na poprawne relacje w rodzinie, atmosferę ciepła, życzliwości i akceptacji jest upragnione i trudne do osiągnięcia, a poczucie odrzucenia społecznego tak nasilone, że jednostki nie radzą sobie z poszukiwaniem korzystnych rozwiązań swojej sytuacji.

Ponadto życie $\mathrm{w}$ rodzinie $\mathrm{z}$ osobą stygmatyzowaną wpływa negatywnie także na partnera, który zdecydował się pomagać byłemu więźniowi. W wielu przypadkach osoby w związkach tego typu nie wytrzymują próby czasu, kiedy nie radzą sobie z problemami byłego więźnia i z własnymi oraz presją społeczeństwa. Często boją się odejść od niego ze względu na trudne do przewidzenia zachowanie, m.in. zachowania agresywne, gwałtowne wybuch złości czy groźby.

Warto przytoczyć kilka przypadków z życia takich rodzin, borykających się z poczuciem odrzucenia ze strony społeczeństwa, stygmatem ze strony rodziny własnej i wreszcie problemów dorastających dzieci, które mają ograniczone możliwości uczestnictwa w życiu społecznym i poczucie przynależności do grup marginalizowanych. A tym samym często ze względu na przeszłość swoich bliskich, zmuszone są (w ich przekonaniu) do podejmowania się zachowań aspołecznych.

Przytoczone przykłady oparte są na faktach autentycznych, uzyskanych w trakcie realizacji badań naukowych w rodzinach skazanych w latach 2001-2011 [Kieszkowska, 2012] oraz aktualnie prowadzone badania rodzin uwięzionych. Zachowana jest pełna anonimowość osób, a niektóre 
wybrane fragmenty opisu sytuacji mogą być zbieżne i podobne do problemów przeżywanych w wielu innych rodzinach będących w sytuacjach trudnych [Kieszkowska 2011/2012]. Zamieszczone przykłady pozostawiono bez komentarza, aby czytelnik po zapoznaniu się z sytuacjami wybranych rodzin, sam mógł poszukać odpowiedzi na nurtujące pytania i zrozumieć potrzebę i konieczność wdrażania działań pomocowych w rodzinie i środowisku lokalnym oraz postrzegać takie rodziny nieco inaczej .

\section{Przypadek $n r 1$}

\section{Odgłos zamykanych krat pozostanie na zawsze w mojej pamięci...}

„(....) podczas zajęć na wykładzie jest mowa o readaptacji więźniów do środowiska lokalnego. Po podaniu tematu już czuję, że znowu mogę nie dać rady, ale przecież nikt nie wie, że ja zdecydowanie lepiej wiem, jakie to szanse oni mają aby powrócić normalnie do życia. Okazuje się, że prowadzący omawia pod kątem formalnym zagadnienie powrotu, pomocy postpenitencjarnej i wreszcie sięga do problemów rodziny i środowiska. Czuję, że już nie dam rady, zaczynam się kręcić, aby się nie rozpłakać. Ktoś ze studentów, zapewne jakichś służb próbuje powiedzieć, kim są byli więźniowie, że dobrze im tak, nikt też się specjalnie nie zastanawia czy społeczeństwo powinno pomagać takim rodzinom, ktoś inny mówi, że nie żałuje ich wcale. A mnie bardzo ciężko. Kiedy nauczyciel nie widzi zrozumienia sytuacji skazanych na wolności, powiada, że pokaże jeszcze film o matkach, które przebywają w zakładzie i ich kontaktach ze środowiskiem. Wszyscy z ciekawością chcą oglądać, a ja wiem, że za chwilę się rozpłaczę. Nikt przecież nie może mi pomóc. W momencie, kiedy słyszę odgłosy funkcjonariuszy z taśmy i dźwięk zamykanych metalowych krat, próbuję się 
jakoś oderwać, sięgam pod ławkę, aby nie patrzeć, wystarczy dobiegający głos. Dławię się już prawie, wreszcie z wielkim bólem serca, prawie resztkami sił próbuje wyjść z sali, aby nie rozpłakać się przy wszystkich. Nauczyciel zaniepokojony wychodzi za mną, widzi że trzęsę się i szlocham, nie pyta od razu, ale próbuje mnie posadzić na krześle i zapytać czy to ze wzruszenia czy mnie coś boli i czy poprosić kogoś do towarzystwa. Muszę pozostać sama. Nikt z tych osób nie może wiedzieć, zniszczą mnie. Mówię, że ze wzruszenia i chce pozostać chwile sama. Upewnia się, że nic mi nie grozi i wraca do studentów. Ja przeraźliwie płaczę, widzę siebie w tych korytarzach podczas odwiedzin w ciąży, pamiętam spojrzenia i komentarze, kiedy przechodziłam, pamiętam komentarze innych więźniów i wreszcie radość, zaniepokojenie i smutek mojego męża, który już za kilka lat miał być na wolności. Wszystkie odgłosy i dźwięki słyszę do dziś (...) czasami myślę, że nasze dziecko, które czasem gwałtownie budzi się w nocy i bardzo się boi, też ma sny z tamtego czasu, kiedy ja potwornie przeżywałam każde wejście do zakładu. Nauczycielka, wychodzi do mnie, patrzy na mnie z wielkim wzruszeniem, ja tylko proszę, żebym nie musiała już wracać do sali. Podaje mi klucz do swojego pokoju i mówi, że za chwilę wyjdzie grupa, a ja mam przejść do pokoju i tam się spotkamy. Pewnie się domyśla, co teraz powiem. Jednak wykonuje polecenie, aby nikt nie zobaczył mnie zapłakanej. Przez trzy lata studiów udało się przetrwać, nie wtajemniczając nikogo w moje problemy. Zastanawiam się co teraz zrobię, czy mogę komuś zaufać. Czy nie pogorszę sobie sytuacji, kiedy i tak jest już zła. Co robić.?....

(...) Tymczasem siada naprzeciwko mnie i spokojnym głosem mówi „widzę, że Pani bardzo ciężko, że sytuacja wyjątkowo trudna, czy mogę jakoś pomóc?". Nie spodziewałam się takiego pytania, myślałam że będzie ciągnąć 
ode mnie wszystkie szczegóły, miałam wrażenie, że ona to wszystko wyczytała z mojej twarzy. Poczułam ulgę, nie muszę wreszcie odkrywać kart, siedziałyśmy przez chwilę w milczeniu i nagle kiedy spojrzałam na jej oczy, w których też były łzy wzruszenia, jednym tchem wyznałam prawdę, jaką to ja mam rodzinę. Że jestem żoną przestępcy, że mam z nim dzieci, ale tak naprawdę to one go wcale nie interesują, ani ja jego też nie. ... on ma jakieś swoje wydumane życie, ciągle wszystkich śledzi, nikomu nie ufa, z nikim się nie spotykamy, z dziećmi się bawi przez chwilę a potem nagle odchodzi, zapomina o wielu sprawach, siedzi kilka godzin bezczynnie i nie wie dlaczego, ma napady złości i wtedy jest nieobliczalny, nie daje rady pracować, bo uważa, że wszyscy go obserwują. Ma kontakt tylko z kolegą z którym dokonał poprzedniego przestępstwa. I że ogólnie jest mi tak źle, bo nawet moja rodzina, przestała nas odwiedzać. Przyszłam na studia, żeby bardziej te problemy zrozumieć i nauczyć się żyć z nimi, ale tu zrozumiałam, że dla mnie nie ma miejsca wśród innych studentów, bo oni nie mogą patrzeć na przestępców

(....) Rozmawiałyśmy długo, uspokoiłam się, wiedziałam, co mogę teraz zrobić. I przede wszystkim jak pomóc moim dzieciom i mężowi. Wychodziłam z tego pokoju już spokojna i wydawało mi się, że na nowo mam siłę, aby walczyć o swoje miejsce na ziemi z moją rodziną i dla tej rodziny. Przecież ja też mam pomagać innym, mam być pedagogiem (...)".

Na kolejnym zjeździe, kiedy zobaczyłam nauczycielkę, miałam ochotę podbiec i opowiedzieć, że może trochę lepiej jest w mojej rodzinie, ale przecież nic się nie zmieniło, jedynie ja miałam więcej siły od tamtego czasu i lepiej radziłam sobie z obowiązkami. Kiedy rozpoczęły się kolejne zajęcia, ta kobieta nie dała za wygraną, stwierdziła, że po ostatnich zajęciach 
powinniśmy jeszcze się zastanowić jak pomóc rodzinom, jak być sąsiadem takich osób. I znowu pojawiły się jak zawsze agresywne wypowiedzi studentów, a ja byłam przerażona, ale tym razem miałam zaufanie, że nauczycielka chce mi pomóc, ale nie byłam do końca pewna. Kiedy kilku śmiałków pochwaliło się, co oni by zrobili z takim osobami, to nauczycielka wtedy zadała wszystkim kilka pytań odnośnie pomocy drugiemu człowiekowi, sytuacjach, kiedy każdy może stać się przestępcą, odpowiedzialności jedni za drugich i pytanie, a gdyby każdy z nas dziś tu był w trudnej sytuacji, to czy go odrzucimy ,ja poczułam dziwny szum w uszach”. Na koniec wiem tylko tyle, że przeczytaliśmy wspomnienia więźnia, którego otoczono opieką w jego miejscowości i dzięki temu jego dzieci, rodzina i on sam „mogli zacząć nowe życie z nadzieją na lepsze jutro”.

Na koniec nauczycielka zapytała, czy nie warto czasem spojrzeć na drugiego człowieka pozytywnie, a może mu podać rękę, może to nas wzbogaci duchowo. Niektórzy ludzie zaczęli nawet opowiadać, że w ich rodzinach zdarzały się takie sytuacje, że tu gdzie jest zrozumienie więźniowie chcą i starają się żyć normalnie w społeczności. Było mi lżej.

Na koniec zapytała, na ile sobie pomagamy bezinteresownie, a może chociaż na do widzenia warto dziś podać rękę, może ktoś z was jest w trudnej sytuacji. Wychodząc z sali podawaliśmy sobie ręce i uśmiechaliśmy się do siebie. Potrzebowałam takiego wsparcia. Zrozumiałam pewne rzeczy i podjęłam się nawet ich zmiany i poprawy w swoim życiu. Wychodząc z sali podeszłam do nauczycielki i wyciągnęłam do niej rękę, mocno uścisnęła i powiedziała, wierzę, że Pani wskrzesi iskrę nadziei w swojej rodzinie, przecież Pani poradzi sobie. Wybiegłam z sali z wielką radością, natychmiast 
zadzwoniłam do dzieci, do męża .... przecież muszę dać radę, kiedy wiem, że nie jestem sama $(\ldots)^{\prime \prime}$.

\section{Przypadek 2}

\section{Trudno dorastać $w$ rodzinie z piętnem}

„Dziś już jestem dorosłą kobietą, w mojej rodzinie nie było nigdy dobrze, bo ojciec alkoholik znęcał się nade mną rodzeństwem i moją matką. Pewnego dnia zwyczajnie ją zabił, trafił do więzienia, a ja z młodszym rodzeństwem pod opiekę babci.

Siostra po skończeniu zawodówki wyjechała do pracy i na stałe pozostała za granicą, brat aktualnie nadużywa alkoholu, ale mieszka w innym mieście, więc nie widzę go na co dzień, ale też nie mogę prosić go o żadną pomoc. Ojca znienawidził i nie chce go znać. Sąsiedzi i znajomi raczej stronią od nas, a aktualnie kiedy zbliża się koniec kary ojca unikają. Osobą, która ma kontakt z ojcem w więzieniu jestem jedynie ja. Pisał do mnie listy jako najstarszego dziecka, prosił o przebaczenie, ale kiedy go odwiedzam(najczęściej z racji świąt i za namową babci)to nie chce myśleć co będzie dalej, bo ja się jego boję. Przez niego nie mieliśmy dzieciństwa, nie wiem co to znaczy przytulić się do matki, rozmawiać z nią, ani też nie wiem czy kiedykolwiek mogę komuś zaufać. Babcia, matka naszej mamy, od jej śmierci wychowywała nas, ale zawsze była zapracowana, bo nie było już nikogo kto mógł nam pomoc. Ja mając lat 16 chodziłam do pracy w chłodni, aby sobie zarobić na książki. Pamiętam, że w szkole dzieci nie chciały się z nami bawić, spotykać po lekcjach, nie bywaliśmy na urodzinach u koleżanek i kolegów. Pewnego razu babcia chciała, aby na moje urodziny przyszły koleżanki z klasy, przygotowała ciasto, czekaliśmy ale nikt nie 
przyszedł. Babcia wtedy powiedziała, że ludzie czasem przez zachowanie dorosłych „krzywdzą ich dzieci, oceniają wszystkich i potępiają, ale przecież dzieci niczemu nie są winne". Potem w nocy bardzo płakała....

Na drugi dzień tylko koleżanka mnie przeprosiła i dała w prezencie dużą czekoladę z orzechami, którą dostała od ciotki. Powiedziała „nie mogę Cię odwiedzać, bo rodzice zabronili, ale nie gniewaj się bo „ja ciebie lubię”. Czasem przynosiła dodatkową kanapkę i dawała, ale tak aby nikt nie widział. Czułam się nieswojo, ale ta kanapka była tak dobra, że smak czuje do dziś, u nas przecież takich rzeczy nie było. Babcia nigdy nie prosiła o pomoc, nikt też z własnej woli pomocy nie proponował. Teraz, kiedy ojciec mi mówi, że wróci do domu, będzie mi pomagał, pójdzie do pracy ogarnia mnie strach. Czy podołam. Chciałabym uciec od tego wszystkiego, a to się wlecze tyle lat. Kiedy to uda się wymazać z pamięci - nie wiem. Niedawno ukończyłam liceum wieczorowe, podjęłam studia, aby móc pracować. Nikomu nie mogę powiedzieć do końca prawdy, aby mnie nie odrzucili, ani też nie mogę z nikim się przyjaźnić. Też chciałabym być szczęśliwa, ale czy jest szansa. Żal mi ojca, kiedy go widzę w więzieniu, ale kiedy wychodzę to jestem wściekła, że ja, a pewnie i w przyszłości (jak mówi babcia) ludzie będą do tego wracali. Nie znam nawet rodziny, tylko nieliczni mają z nami sporadyczny kontakt. Myślę, czasem, że jestem też uwięziona, bo tak naprawdę się czuję, szczególnie kiedy kłaniam się ludziom, a oni odwracają głowę i udają, że nie słyszą lub z trudem odpowiadają. Wiele razy myślałam, żeby wyjechać i na nowo rozpocząć życie. Szkoda mi babci, bo ona teraz potrzebuje opieki, przecież troszczyła się o nas. Nie wiem co zrobię ..nie wiem czy ten ojciec powinien mieszkać ze mną?..." 


\section{Przypadek 3}

\section{Życie na uboczu}

„Nigdy nie miałem pojęcia, dlaczego nasza rodzina ciągle żyje jakoś trochę na uboczu. Kiedy poznałem dziewczynę i chciałem się z nią umawiać, na poważnie chodzić z myślą o ożenku, to nagle okazało się że, mimo że ona mnie darzy sympatią to musi się rozstać ze mną. Ponieważ mi na niej zależało więc postanowiłem wyjaśnić co może być przyczyną, skoro do tej pory było wszystko dobrze. Kiedy odwiedziłem ją w domu, rodzice jej odbyli ze mną poważną rozmowę, że ich córka zmieniła zdanie, ale i oni nie będą jej skłaniać do niczego, bo sami chcieli też ją namawiać do zmiany decyzji wyboru partnera.

Na pytanie z jakiego powodu, poinformowali mnie, że mój wujek a brat mojego ojca przebywał w latach dziewięćdziesiątych w więzieniu za pobicie sąsiada ze skutkiem śmiertelnym i nie chcą, aby ich córka do takiej rodziny należała.

Byłem zaskoczony tą informacją, bo nigdy w mojej rodzinie o tym się nie mówiło, ale sąsiedzi i znajomi nie byli też nigdy w stosunku do nas przyjaźnie nastawieni, mimo, że zachowywaliśmy się poprawnie.

W drodze do domu ogarniały mnie na przemian: wściekłość, niedowierzanie, lęk, wstyd, upokorzenie, natomiast rodzice ze smutkiem przyjęli wiadomość i jak sami powiedzieli, że pomimo, że postępują jak należy, żyją uczciwie, to przez te lata mają odczucie, że nie należą do społeczności lokalnej. Gdyby wiedzieli, że tak będzie to dla dobra swoich dzieci zmieniliby miejsce zamieszkania lub nawet nazwisko. Czuję się dziś z tym bardzo podle. Nie wiem co lepsze wiedzieć od początku czy już jako 
dorosły człowiek, który ma plany, marzenia i nagle świat runął pod nogi... (...).

\section{Konkluzje}

Obecnie w naszym kraju, ze względu na wysoki wskaźnik przestępczości społeczeństwa, jest bardzo dużo rodzin tego typu. Jednak praca z rodziną uwięzioną pozostaje na samym końcu w realizacji zadań ze względu na szereg ważnych innych kwestii społecznych. Nie ma miejsca na analizowanie problemów rodzin, które przeżywają wiele dylematów związanych z trudnymi sytuacjami ich bliskich i własnymi związanych z osadzeniem czy powrotem na wolność osób karanych. Dzieci w tych rodzinach pozostawiono samych sobie, zarówno w domu jak i na terenie szkoły - jedynie rówieśnicy wykonują rozliczenia na miarę własnych pomysłów i akceptacji takich zachowań przez dorosłych.

Te i wiele innych pytań ciągle nurtuje społeczeństwo, ale w obecnej sytuacji Oni (rodziny i skazani) nadal mają plany i marzenia, potrzebują profesjonalnej pomocy zarówno indywidualnej, rodzinnej jak i środowiskowej. Jednak czy społeczeństwo jest gotowe i otwarte na rozwiązywanie tych problemów i czy jest odpowiednio przygotowana sieć instytucji mogących realizować określone formy wspierania i aktywizowania osób w sytuacjach kryzysowych.

Instytucjonalne wsparcie powinno być kompleksowe i skierowane do wszystkich członków rodziny a nade wszystko ukierunkowane na wsparcie i pomoc dzieciom z rodzin uwiezionych, przeżywającym rozstanie i upokorzenie oraz ból i wstyd w relacjach rówieśniczych. 
Przystosowanie się do nowej sytuacji wymaga nie tylko czasu, ale przede wszystkim nabywania kompetencji radzenia sobie z problemami przez daną rodzinę i przełamywanie barier stygmatu poprzez wypracowanie konstruktywnych zachowań i stworzenie optymalnych warunków środowiskowych dla rodziny przy udziale specjalistów i środowiska lokalnego. Te propozycje stanowią pewną prośbę skierowaną do społeczeństwa, aby zechciało w swojej okolicy dostrzegać osoby potrzebujące wsparcia i określonych form pomocy.

\section{Bibliografia:}

Ambrozik W., Proces readaptacji społecznej i jego istota, [w:] B. Urban, J. M. Stanik (red.), Resocjalizacja, Wyd. PWN, Warszawa 2007.

Kieszkowska A., Rodziny uwięzionych, Wyd. UJK, Kielce 2011/2012.

Kieszkowska A., Inkluzyjno-katalaktyczny model reintegracji społecznej skazanych. Konteksty resocjalizacyjne, Oficyna Wydawnicza „Impuls”, Kraków 2012.

Kotlarska-Michalska A., Rusanen T., Niemela P., Poczucie bezpieczeństwa społecznego w świetle badań polsko-fińskich, Wyd. UAM, Poznań 1977.

Marczak M., Dylematy zwiq̨zane z rodzicielstwem osób uwięzionych, [w:] S. Przybyliński (red.), Poszukiwania człowieka w nieegalitarnym świecie horyzonty resocjalizacyjne, Wyd. OWS, Olsztyn 2011.

Muskała M., Więź osadzonych recydywistów ze środowiskiem, Wyd. PTP, Poznań 2006. 
Pawełek K., Pełnienie roli ojca przez osadzonych mężczyzn, [w:] Ambrozik W., Machel H., Stępniak P. (red.), Misja Służby Więziennej a jej zadania wobec aktualnej polityki karnej i oczekiwań społecznych, Poznań - Gdańsk Warszawa - Kalisz 2008.

Pawełek K., Powrót więźniów do społeczeństwa, Wyd. UAM, Poznań 2009. 